\title{
Middle-Late Pleistocene Paleo-Climate and Paleo-Altimetry of the Centre of Tibetan Plateau Indicated by the Sporopollen Record of Well QZ-4
}

\author{
Jianglin He ${ }^{1,2 *}$, Jian Wang1,2, Weipeng Li ${ }^{3,4}$, Wei Sun ${ }^{1,2}$ \\ ${ }^{1}$ Chengdu Institute of Geology and Mineral Resources, Ministry of Land and Resources, Chengdu, China \\ ${ }^{2}$ Key Laboratory for Sedimentary Basin and Oil and Gas Resources, Ministry of Land Resources, Chengdu, China \\ ${ }^{3}$ Land and Resources College, China West Normal University, Nanchong, China \\ ${ }^{4}$ Key Laboratory of Mountain Environment Evolution and regulation, Institute of Mountain Hazards and Environment, Chinese \\ Academy of Sciences, Chengdu, China \\ Email: ${ }^{*}$ hj1998@163.com
}

How to cite this paper: He, J.L., Wang, J., Li, W.P. and Sun, W. (2017) Middle-Late Pleistocene Paleo-Climate and Paleo-Altimetry of the Centre of Tibetan Plateau Indicated by the Sporopollen Record of Well QZ-4. Journal of Geoscience and Environment Protection, 5, 148-165. https://doi.org/10.4236/gep.2017.58013

Received: July 7, 2017

Accepted: July 31, 2017

Published: August 3, 2017

Copyright ( 2017 by authors and Scientific Research Publishing Inc. This work is licensed under the Creative Commons Attribution International License (CC BY 4.0).

http://creativecommons.org/licenses/by/4.0/ (c) (i) Open Access

\begin{abstract}
The core sample from well QZ-4 is an important climate archive for the central Tibetan Plateau in the middle-late Pleistocene. In this work, a detailed pollen analysis of it is carried out to provide a preliminary insight into the paleo-climate and paleo-altimetry change in the central Tibetan Plateau. It can be concluded that the pollen assemblage can be obviously divided into two pollen zones, Pollen zone I (251.1 - $314 \mathrm{~m}$ in depth, 120.0 - $345.8 \mathrm{ka} \mathrm{BP}$.) and Pollen zone II (200 - $251.1 \mathrm{~m}$ in depth, $105.4-120 \mathrm{ka} \mathrm{BP}$.). The paleo-climate during pollen zone I deposition period was comparatively colder and wetter than it during the pollen zone II deposition period. After Gonghe Movement, the center of Tibetan Plateau was uplifted about $300 \mathrm{~m}$ (from $3500-3700 \mathrm{~m}$ to $3800-4000 \mathrm{~m}$ in elevation). The wind was changed from horizontal or downward direction to upward direction, in the study area. In the central of Tibetan Plateau, the climate change seems to be mainly driven by global climate change, and that tectonic uplift may have been a subordinate influence at the middle-late Pleistocene.
\end{abstract}

\section{Keywords}

Tibet Plateau, Mid-Pleistocene, Palaeo-climate, Paleo-Altimetry, Gonghe Movement, Well QZ-4

\section{Introduction}

The Tibetan Plateau is not only the largest and highest mountain plateau on 
Earth, but it is also the site of the first successful terrestrial gas hydrate exploration in China [1]. In recent years, considerable attention has been focused on the study of the correlation between the uplift of the Tibetan Plateau and Quaternary climate evolution [2], which is not only beneficial to the study of global climate change, but it is also beneficial to the study of permafrost surveys and the exploration of gas hydrates in the Tibetan Plateau. However, the existing results come from the surrounding area [3] [4], and little study in the central Tibetan Plateau has been reported (Figure 1).

Previous studies have shown that, globally, the hottest period since the middle Pleistocene was at approximately $120 \mathrm{ka} \mathrm{BP}$, which is recorded in the ice sheet above Lake Vostok in the southern hemisphere [7] and in Greenland [8] in the northern hemisphere. North Greenland Eemian Ice Drilling (NEEM) surface

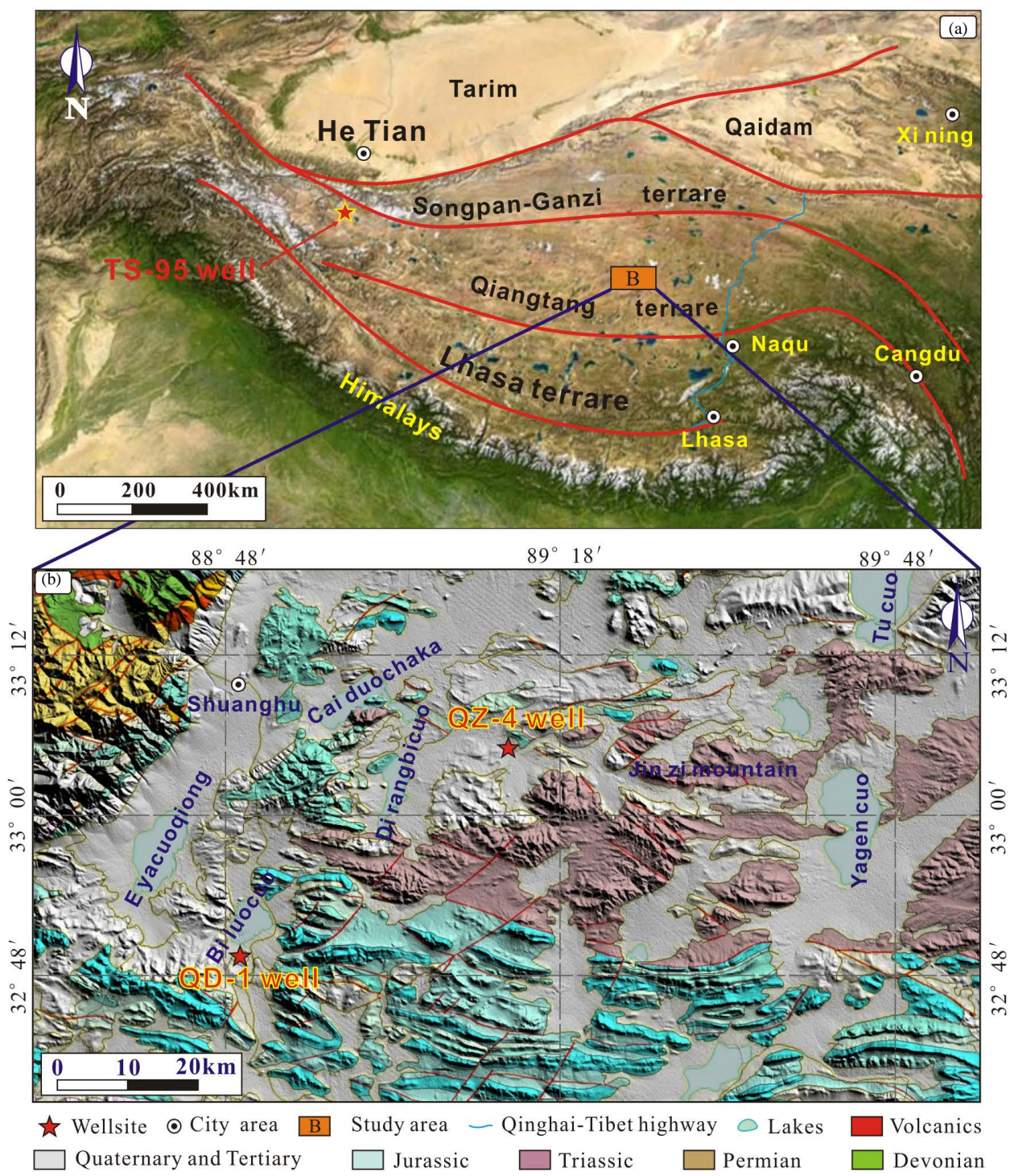

Figure 1. (a) Map of the Tibet Plateau showing the location of the study area and well TS-95 [5] [6], (b) Map of the Shuanghu area showing the geomorphological features in the study area and the location of well QZ-4 and well QD-1. 
temperatures after the onset of the Eemian ( $126 \mathrm{ka}$ ) peaked at $8^{\circ} \mathrm{C} \pm 4^{\circ} \mathrm{C}$ above the mean of the past millennium [8]. In the central Tibetan Plateau, the thermoluminescence (TL) dating of well QD-1 [9], the 14C and 230Th/234U dating of well TS-95 [5] [6] and the Electronic Spin Resonance (ESR) dating of well QZ-4 show that the transition section of the colour sequence in the three wells was deposited at approximately $120 \mathrm{ka}$ (Figure 2). Furthermore, the last rapid uplift of the Tibetan Plateau started at $150 \mathrm{ka} \mathrm{BP}$, which is referred to as the Gonghe Movement [10]. After the Gonghe Movement (Figure 3), the average elevation reached almost $4000 \mathrm{~m}$, at which the East Asian monsoon was apparently affected by the Tibetan Plateau [10] [11]. The paleo-climate study based on the cores of well QZ-4 will benefit the study of the correlation between climate changes in the central Tibetan Plateau and global climate change in the middle-late Pleistocene, which will contribute to the study of the correlation between the uplift of the Tibetan Plateau and Quaternary climate evolution.

In this work, the thickest Quaternary sedimentary formation in the central Tibetan Plateau was drilled in well QZ-4 (Figure 1), and the most complete core was collected. The cores are characterized by a colour sequence with three colour features: 1) the yellow subsequence (with dark yellowish-brown and brownish-red

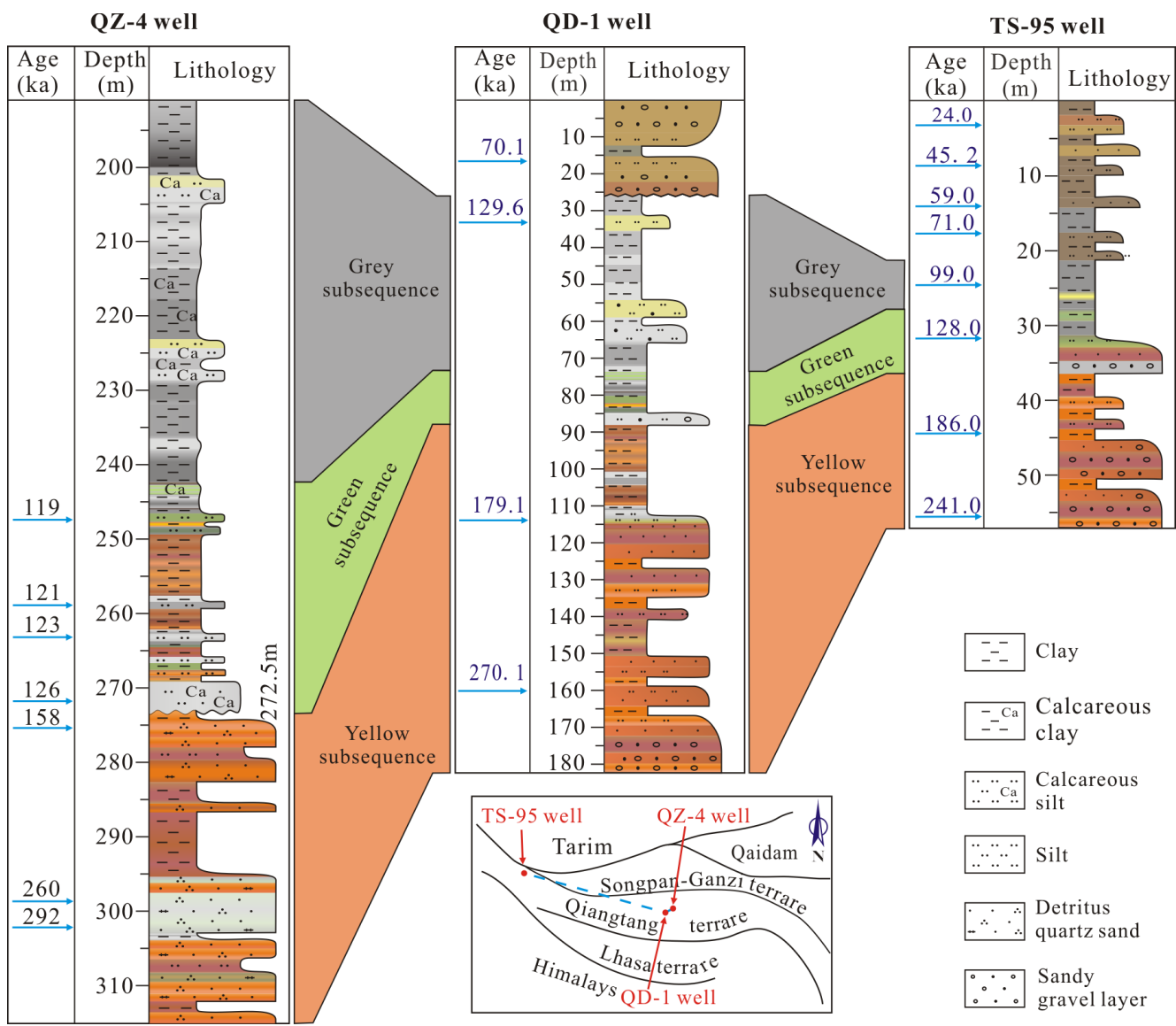

Figure 2. The lithological association and the ESR, TL and ${ }^{14} \mathrm{C}$ and ${ }^{230} \mathrm{Th} /{ }^{234} \mathrm{U}$ dating results of this color sequence in well QZ-4, well QD-1 [9] and well TS-95 [5] [6] with depth scale. The core images of this color sequence in well QZ-4. 


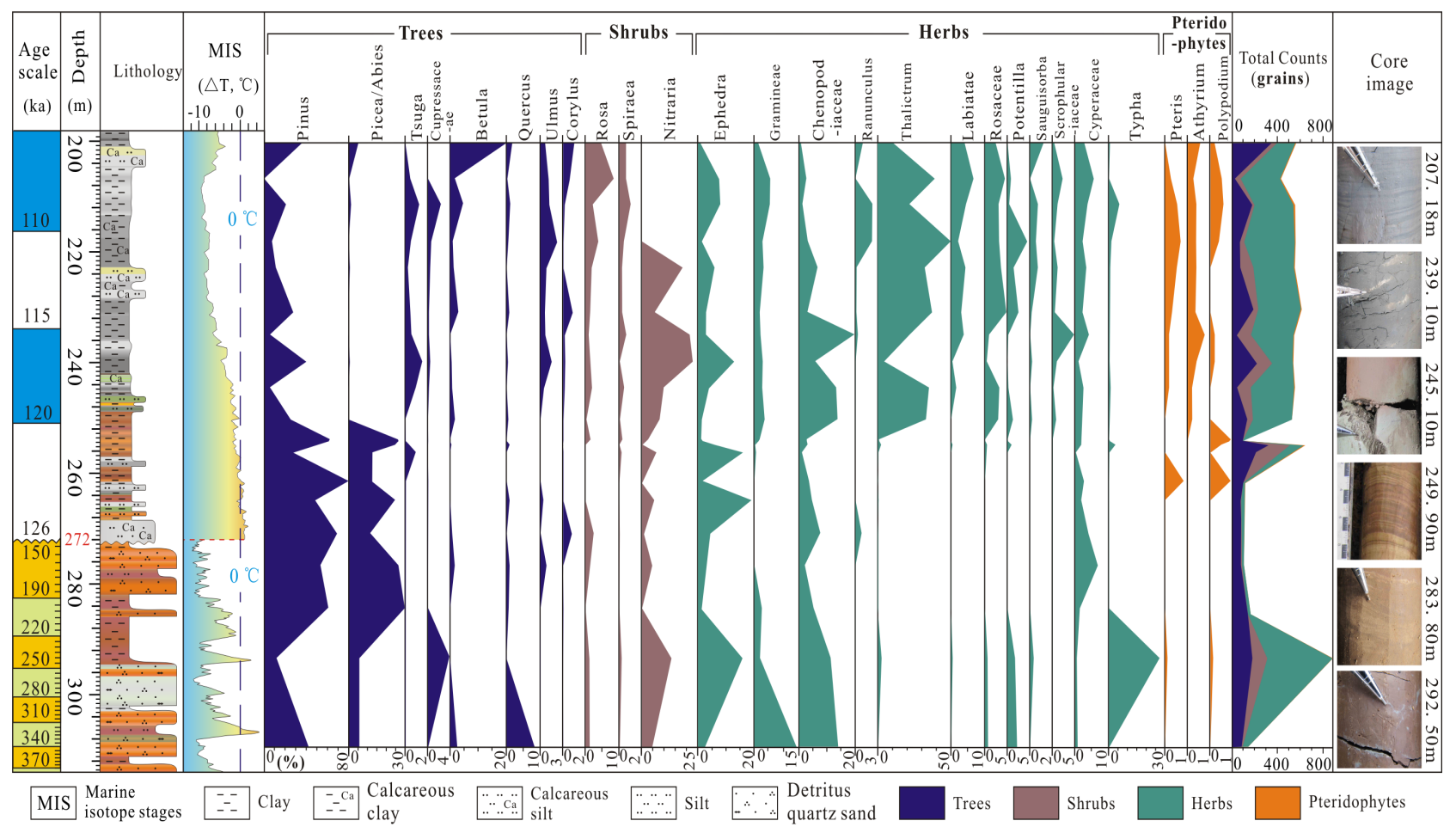

Figure 3. Pollen and Spore percentage diagram for the well QZ-4 plotted against the depth and date. The data of the MIS curve are come from the website: https://commons.wikimedia.org/wiki/File:Vostok_Petit_data.svg?uselang=zh-sg.

colour) at the depth from $272.48 \mathrm{~m}$ to $314 \mathrm{~m}, 2$ ) the grey subsequence (with dark grey and whitish-grey colour) at the depth from $198 \mathrm{~m}$ to $240 \mathrm{~m}$, and 3) the transition section (with light greyish-green colour) interbedded with the brown and grey clay at the depth from $240 \mathrm{~m}$ to $272.48 \mathrm{~m}$, which is consistent with the colour sequences observed in wells QD-1 [9] and TS-95 [6], which are located in the central and north western Tibetan Plateau, respectively (Figure 2). The cores drilled in well QZ-4 are desirable archives for the study of climate change in the central Tibetan Plateau. In this paper, we present a detailed pollen analysis of the well QZ-4 in an effort to provide preliminary insight into the climate and the elevation change recorded in it.

\section{Sample and Methods}

Well QZ-4 is located in the central Tibetan Plateau, approximately $50 \mathrm{~km}$ east of Shuanghu County at $89^{\circ} 14^{\prime} \mathrm{E}$ and $33^{\circ} 5^{\prime} \mathrm{N}$, with an elevation of $4932 \mathrm{~m}$. The surrounding area is a flat terrain, in which the maximum elevation difference is smaller than $50 \mathrm{~m}$. The rivers in this area are seasonal rivers, which are formed during the rainy season and flow west into Dirangbicuo Lake and Caiduochaka Lake (Figure 1). The bedrock around the QZ-4 well is the Tumengela Formation, which is composed of quartz-lithic sandstone and was deposited in a deltaic floodplain environment in the Late Triassic [12]. The total depth of this well is $314 \mathrm{~m}$. The cores in the well were well collected at $190-314 \mathrm{~m}$ depth, partly collected at $0-110 \mathrm{~m}$ depth, and absent at $110-190 \mathrm{~m}$ depth. Basing on the core 
samples, core recovery, detritus and indicators of sedimentary environments (e.g., colour, lithologic characters, grain size, grain shape, particle roundness, sedimentary structures, and fossil assemblage) in the core samples, the stratigraphic sequence drilled in well QZ-4 can be subdivided into two sedimentary sequences.

The first sequence, at 0 - $198 \mathrm{~m}$ in depth, is a regressive depositional sequence, which consists of semi-deep lake facies, shallow lake facies, lake shore facies, meandering stream facies and flood plain from the deep to shallow layers in sequence. These facies are characterized by black grey clay and grey clay, light grey silty clay, light grey, yellow sand, and a yellow-brown sandy gravel layer, respectively.

The second sequence, at 198 - $314 \mathrm{~m}$ depth, consists of several transgressive-regressive depositional sequences, which consist of shallow lake facies, lake shore facies and semi-deep lake facies. In this sequence, the semi-deep lake facies is characterized by black grey clay, grey clay, dark yellowish-brown clay and brownish-red clay, with horizontal bedding at depths of 198 - 199.9 m, 203.18 $221.68 \mathrm{~m}, 227.18-240.8 \mathrm{~m}, 247.88$ - $260.78 \mathrm{~m}$ and $281.33-293.98 \mathrm{~m}$. The shallow lake facies is characterized by yellow-brown silty clay interlayered with thin light-greysilty clay, brown clay, and white grey clay at depths of $199.9-203.18$ m, 221.68 - $227.18 \mathrm{~m}, 240.8$ - $247.88 \mathrm{~m}, 260.78$ - $278.31 \mathrm{~m}, 293.98-296.18 \mathrm{~m}$ and 302.4 - $313.0 \mathrm{~m}$. The lake shore facies is characterized by yellow-brown sand interlayered with white grey sand and brown clay at depths of $278.31-281.33 \mathrm{~m}$, 296.18 - $301.7 \mathrm{~m}$ and 313.0 - $314 \mathrm{~m}$ (Figure 2).

A total of 20 samples with $5 \mathrm{~m}$ intervals were collected from the well QZ-4 for palynological analysis. Samples weights of $200 \mathrm{~g}$ were used to prepare pollen residues for the upper $244 \mathrm{~m}$ depth, and samples weights of $300 \mathrm{~g}$ were used to the lower depths. Samples were mostly prepared using standard techniques [13], involving alkali digestion, treatment with $10 \%$ cold $\mathrm{HCl}, 10 \%$ hot $\mathrm{KOH}, 46 \%$ hot HF, and Erdtman's acetolysis, staining with safranin, dehydration with tertiary butyl alcohol, and mounting in silicone oil. Prior to alkali digestion, moss polsters and soils were dispersed in distilled water and sieved $(200 \mathrm{~mm})$ to remove coarse detritus and sand. Lycopodium tablets were added to the samples to allow for estimation of pollen concentrations [14]. All samples have been studied under microscopes at Nanjing Institute of Geology and Palaeontology, Academic Sinica (Nanjing, China) and The Institute of Hydrogeology and Environmental Geology, Chinese Academy of Geological Sciences (Shijiazhuang, China). Leica microscope at a magnification of 400 was used for pollen identification and counting. More than 100 pollen grains were counted for each sample. Pollen abundance was expressed as percentages calculated using the total pollen sum.

\section{Results}

Most of the studied samples yielded rich, well-preserved palynomorph assemblages, with the identified sporomorphs representing about 75 taxa, including 
arboreal taxa, e.g. Pinus, Picea, Picea, Tsuga, Cupressaceae, Betula, Carpinus, Alnus, Juglans, Quercus, Fagus, Ailanthus, Ulmus, Tilia, Moraceae, Salix, Corylus, Ilex, Oleaceae, as well as scrubby and herbaceous taxa, e.g. Lonicera, Sambucus, Rosa, Spiraea, Rhododendron, Caragana, Reaumuria, Hippophae, Nitraria, Ephedra, Gramineae, Chenopodiaceae, Compositae, Chrysanthemum, Artemisia, Aster, Xanthium, Ranunculaceae, Ranunculus, Thalictrum, Polygonum, Rumex, Labiatae, Prunella, Euphorbia, Rosaceae, Potentilla, Sauguisorba, Papilionatae, Primula, Rubiaceae, Scrophulariaceae, Lythraceae, Cruciferae, Araliaceae, Geranium, Clerodendron, Gentiana, Solanaceae, Sedum, Umbelliferae, Saxifraga, Lilium, Arenaria, Macleaya, Urticaceae, Cyperaceae, Typha, and some fern spores, including Lycopodium, Sellaginella, Adiantaceae Pteris, Athyrium, Polypdiaceae, Polypodium, Lepisorus, Filicale. Some algal remains (e.g. Pediastrum) were also detected. The total spore and pollen sum was used to calculate the percentage of various spore and pollen taxa. As shown in (Figure 3), the pollen assemblage can obviously divided into two pollen zones.

Pollen zone I (251.1 - $314 \mathrm{~m}$ in depth, 120.0 - $345.8 \mathrm{ka} \mathrm{BP}$.) is characterised by single species and low pollen concentrations. The average pollen concentration is around 0.4 grain/g, except the sample at $295.0 \mathrm{~m}$ in depth with 3.1 grain/g. In this pollen zone, the pollen species are particularly characterized by high abundance of tree, a few herb, shrubs and fern spores. The maximum proportion of tree pollen reaches $86.5 \%$, with an average of $66.2 \%$. The tree pollen principally includes Pinus (10.5\% - 71.9\%, av. 45.31\%), Picea (5.6\% - 29.0\%, av. $17.4 \%)$ (Figure 3). Tsuga, Cupressaceae, Betula, Quercusetc. are occasionally seen in some samples. The average content of herb pollen is $19.2 \%$. The herbs principally include Ephedra (0.9\% - 18.9\%, av. 7.0\%), Chenopodiaceae (1.1\% - 13.9\%, av. 5.4\%), Cyperaceae (0.2\% - 6.8\%, av. 2.1\%) (Figure 3). Gramineae, Artemisia, Labiatae, Rosaceae, Typha etc. are occasionally seen in some samples, especially the Typha composes $25.9 \%$ of the total pollen sum at $295.0 \mathrm{~m}$ in depth. The maximum proportion of shrub pollen reaches $46.4 \%$, with an average of $9.7 \%$. The shrub principally includes Nitraria (0.5\% - 12.7\%, av. 4.2\%) (Figure 3). Lonicera, Rosa etc. are occasionally seen in some samples, especially the Lonicera composes $38.8 \%$ of the total pollen sum at $256.9 \mathrm{~m}$ in depth. The fern spores are sporadically present in a few samples. The maximum proportion of fern spores is smaller than $0.9 \%$.

Pollen zone II (200 - $251.1 \mathrm{~m}$ in depth, 105.4 - $120 \mathrm{ka}$ BP.) is characterised by multiple species and high pollen concentrations. The average pollen concentration is around 2.8 grain/g. In this pollen zone, the pollen species are particularly characterized by a high abundance of herb, a few tree, shrubs and fern spores. The maximum proportion of herb pollen reaches $80.3 \%$, with an average of 60.9\%. The herb principally includes Thalictrum $(4.2 \%-50.5 \%$, av. $28.8 \%)$, Chenopodiaceae (0.5\% - 19.5\%, av. 6.8\%), Ephedra (0.7\% - 12.9\%, av. 4.7\%), Gramineae (1.3\% - 5.4\%, av. 3.1\%) (Figure 3). Artemisia, Ranunculus, Labiatae, Rosaceae etc. are occasionally seen in some samples. The maximum proportion 
of tree pollen reaches $61.9 \%$, with an average of $24.5 \%$. The trees principally are Pinus (0.5\% - 35.6\%, av. 16.11\%) (Figure 3). Picea, Tsuga, Cupressaceae, Betula, Quercus etc. are occasionally seen in some samples. The maximum proportion of shrub pollen reaches $24.1 \%$, with an average of $13.6 \%$. The shrub principally include Nitraria $(0.5 \%-21.4 \%$, av. 9.0\%), Rosa $(0.4 \%-8.6 \%$, av. $2.9 \%)$ (Figure 3). Lonicera, Spiraea, Hippophae, Reaumuria etc. are occasionally seen in some samples. The maximum proportion of fern spores reaches $1.7 \%$, with an average of $1.0 \%$. The fern spores principally is Athyrium (0.2\% - 0.8\%, av. $0.4 \%)$, Pteris, Polypodium, Lepisorus etc. are sporadically present in a few samples.

\section{Discussion}

\subsection{Ecologic Environment}

The sporopollen assemblage of pollen zone I is characterized by high percentages of arboreal taxa, e.g. Pinus, Picea and Abies, and low percentages of scrubby and herbaceous taxa. However, the sporopollen assemblage of pollen zone II is characterized by high percentages of shrub species and herbaceous taxa, e.g. Thalictrum, Rosaceae and Labiatae, and low percentages of arboreal taxa (Figure 3).

Many studies of the representation of Piceal Abies-pollen in modern sporopollen assemblages indicate that such assemblages are highly indicative of autochthonous vegetation [15] [16]. In pollen zone I, the average percentage of $\mathrm{Pi}$ cea and Abies is $17.4 \%$ (5.6\% - 29.0\%), which is suggesting that spruce and fir forests developed widely in the central of Tibetan Plateau. On the Tibetan Plateau today, Picea and Abies are the main representatives of sub-alpine dark coniferous forests and are principally distributed Gongga Mountain, Himalaya, Nyainqentanglha and Hengduan Mountains [15] [17]. However, in the pollen zone II, Picea and Abies are occasionally seen in some samples, with average percentage of $0.8 \%(0 \%-4.9 \%)$. The pollen zone II is mainly composed of shrub species and herbaceous taxa, such as Labiatae [17], Thalictrum [17] and Rosaceae (Yashiro et al., 2010) which are the major herb species of alpine shrub meadow in Tibetan Plateau. Hence, it can be deduced that during pollen zone I deposition period, the zonal vegetation in the central of Tibetan Plateau should have been subalpine dark coniferous forests. However, it has been alpine shrub meadow during pollen zone II deposition period.

\subsection{Paleo-Temperature Interpretation}

The study of Cordova et al. [18] shows that Quercus-Ulmus-Poaceae pollen assemblage zone and the development of a chernozem soil suggest cool-dry climate conditions. In well QZ-4, the Quercus-Ulmus-Poaceae pollen assemblage is observed in the pollen zone II, and the chernozem soil section is observed in this zone too (Figure 3). Meanwhile, it is known that Pinus prefers cool weather [19]. In the well QZ-4, the Pinus is observed in the both pollen zones. It is indicated that both the two pollen zones are deposited in the cool temperature re- 
gime.

On the other hand, Chenopodiaceae, Cyperaceae and Lamiaceae are suggesting dry and cold conditions [20]. In pollen zone II, Chenopodiaceae, Cyperaceae and Lamiaceae are richer than them in the pollen zone I. Meanwhile, the modern mean annual temperature is generally above $4^{\circ} \mathrm{C}$ in the sub-alpine dark coniferous forests [15] and is no higher than $-1^{\circ} \mathrm{C}$ in the alpine shrub meadow in Tibetan Plateau [21].

Hence, it can be concluded that both pollen zone I and II are deposited in a cool climate environment. The climate is comparatively cooler during the pollen zone II depositional period than the pollen zone I depositional period. In the central of Tibetan Plateau, the temperature was slightly declined in the middle-late Pleistocene.

\subsection{Paleo-Humidity Interpretation}

The study of Ji et al. [22] shows that the Thalictrum is normally in arid climates. In well QZ-4, Thalictrum is rich in pollen zone II (4.2\% - 50.5\%, av. 28.8\%), but absent in the in the pollen zone $\mathrm{I}$, which is indicating that regional climate is comparatively drier during the pollen zone II depositional period than the depositional period of pollen zone I.

Ephedra is typical desert plants and is often used as indicator of dry climate [23]. It is a perennial shrub and it is a very effective sand-binder. In Saudi Arabia, it is associated with sand dunes formation, especially the mobile, non-saline and low moisture content ones [24]. In the pollen zone I, the Ephedra principally is rich in the sand strata and absent in the clay strata. However, in pollen zone II, it is obviously richer in clay strata than sand strata (Figure 3). It is indicated that the Ephedra is principally associated with sand dunes formation in the pollen zone I. Nevertheless, in pollen zone II, the climate is so dry that the Ephedra is principally associated with the moisture. The regional climate is comparatively drier during the pollen zone II depositional period than the depositional period of pollen zone I.

Nitraria is one of dominant species in desertified steppe and desert [25]. Gramineae is better represented in dry than in moist forest [26], and it is taken as dry climate [27]. Chenopodiaceae characterize dry environments [23] [28]. Rosaceae and Rosa are suitable for cool-dry conditions [29]. The Nitraria, Chenopodiaceae, Gramineae, Rosaceae and Rosa are enriched in pollen zone II (Figure 3 ), which are indicated that regional climate is comparatively drier during the pollen zone II depositional period than the depositional period of pollen zone I.

In brief, climate is comparatively drier during the pollen zone II depositional period than the depositional period of pollen zone I. In the central of Tibetan Plateau, the climate was dried in the middle-late Pleistocene.

\subsection{Paleo-Altimetry Interpretation}

Traditionally, air temperature decline with increasing elevation in free air (lapse rate) is considered the primary factor determining the position and composition 
of altitude-related vegetation zones [30]. The approaches basing on the correlation of temperature and altitude are applied to the reconstruction of paleo-altimetry [15], such as isotopes[31], atmospheric pressure, enthalpy, $\mathrm{pCO}_{2}$, fossils, the $\delta \mathrm{D}$ of leaf-waxes and sporopollen assemblages. However, the practice shows that surface temperatures do not depend simply on elevation. For example, there is no trees growing in the area higher than $4500 \mathrm{~m}$ in the central of Tibet, such as the mean annual temperature is about $-0.9^{\circ} \mathrm{C}$ in the Bange county where the elevation is about $4500 \mathrm{~m}$ (Figure 4). However, multiple species of plant grow in the cold region such as the Mohe country in the Northeast of China. The mean annual temperature is at about $-5.5^{\circ} \mathrm{C}$ in Mohe country where the elevation is only about $400 \mathrm{~m}$ (Figure 4). Song et al. [30] suggested that palaeo-elevation can be deduced by enthalpy which is a combination of both temperature and humidity at a constant pressure. In fact, the air pressure is declining with increasing of elevation. The quantitative study of paleo-altimetry would be much more complex than existing research. Up to now, in the study area, there have been no quantitative temperature data (such as Uk'37 and TEX86), humidity data and air pressure data in middle-late Pleistocene. In present, the analogy analysisis likely more credible than quantitative estimation of palaeo-elevation which is based on the temperature, humidity and air pressure.

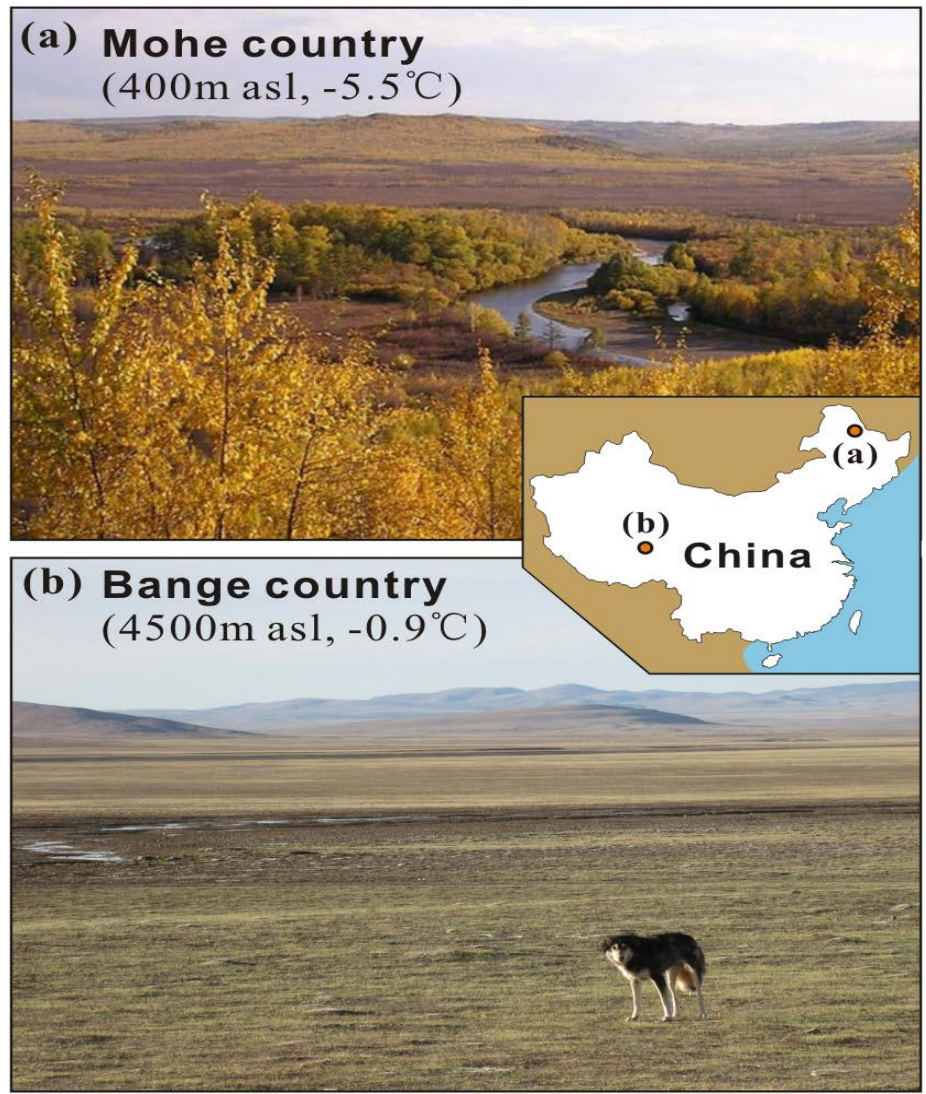

Figure 4. The vegetation distribution is not simply dependent on elevation, such as the present vegetation landscape in Mohe country [35] is obviously different from it in the Bange country [36]. 
Fossil pollen is almost ubiquitous and this makes it attractive as the basis of a possible palaeoaltimeter. Based on their presumed Nearest Living Relatives, the climate and altitude can be studied through their taxonomic affinity and assumptions about past environmental tolerances [15] [30] [32]. In the eastern Tibetan Plateau, the distribution of modern pollen assemblages had been well study by $\mathrm{Li}$ et al. [17], Zhang et al. [33] and Cheng and Luo [34] in the altitudinal transect from 1100 to $4500 \mathrm{~m}$ (Table 1). Based on previous work, the paleo-elevation of

Table 1. Modern altitudinal ranges of taxa and the percentage content of taxa in each pollen zone.

\begin{tabular}{|c|c|c|c|c|c|c|c|c|}
\hline & Pollen/Spore & $\begin{array}{c}\text { Content in } \\
\text { Pollen zone II (\%) }\end{array}$ & $\begin{array}{c}\text { Content in } \\
\text { Pollen zone I (\%) }\end{array}$ & $\begin{array}{l}\text { Credible upper } \\
\text { limit }(\mathrm{m})\end{array}$ & $\begin{array}{l}\text { Maximum } \\
\text { reported }(\mathrm{m})\end{array}$ & $\begin{array}{l}\text { Minimum } \\
\text { reported }(\mathrm{m})\end{array}$ & $\begin{array}{l}\text { Credible lower } \\
\text { limit }(\mathrm{m})\end{array}$ & References \\
\hline 1 & Pinus & 19.54 & 38.63 & 4200 & 4200 & 1200 & 1200 & [30] \\
\hline 2 & Piceal Abies & 0.97 & 16.76 & 3700 & 4200 & 2300 & 2700 & [17] [30] \\
\hline 3 & Tsuga & 0.52 & 0.22 & 3200 & 3200 & 2800 & 2800 & {$[30]$} \\
\hline 4 & Cupressaceae & 0.48 & 1.32 & 4500 & 5300 & 1700 & 3700 & [17] [30] \\
\hline 5 & Betula/ Carpinus & 4.41 & 0.62 & 3700 & 2800 & 780 & 2800 & [17] [30] \\
\hline 6 & Alnus & 0.38 & 0.18 & 2800 & 2800 & 780 & 1900 & [30] \\
\hline 7 & Juglans & 0.66 & 0.13 & 2700 & 3300 & 1300 & 1900 & [30] \\
\hline 8 & Quercus & 0.68 & 0.92 & 2400 & 4000 & 1900 & 1900 & [17] [30] \\
\hline 9 & Ulmus & 1.24 & 0.04 & 2800 & 2800 & 2100 & 2100 & [30] \\
\hline 10 & Tilia & 0.02 & 0.00 & 2900 & 2900 & 700 & 700 & [17] [30] \\
\hline 11 & Salix & 0.05 & 0.09 & 4000 & 5100 & 2300 & 2800 & [17] [30] \\
\hline 12 & Corylus & 0.43 & 0.04 & 2800 & 2800 & 2600 & 2600 & [30] \\
\hline 13 & Ilex & 0.00 & 0.13 & 3600 & 3600 & 900 & 900 & [30] \\
\hline 14 & Oleaceae & 0.07 & 0.00 & 4000 & 4000 & 860 & 860 & {$[30]$} \\
\hline 15 & Lonicera & 0.93 & 10.78 & 3800 & 5200 & 1200 & 1500 & [30] [37] \\
\hline 16 & Rosa & 3.28 & 1.10 & 5600 & 5600 & 860 & 860 & [30] \\
\hline 17 & Spiraea & 0.43 & 0.09 & 4800 & 4800 & 3800 & 3800 & [30] \\
\hline 18 & Rhododendron & 0.05 & 0.00 & 4500 & 5490 & 450 & 3700 & [17] [30] \\
\hline 19 & Hippophae & 0.48 & 0.13 & 5200 & 5200 & 1000 & 1000 & [30] \\
\hline 20 & Ephedra & 5.47 & 13.07 & 5300 & 5300 & 2400 & 3500 & [30] [38] [39] \\
\hline 21 & Gramineae & 3.57 & 2.11 & 5600 & 5600 & 650 & 3800 & [30] [40] [41] \\
\hline 22 & Chenopodiaceae & 8.10 & 7.26 & 5500 & 5500 & 2000 & 2000 & [30] \\
\hline 23 & Artemisia & 0.43 & 0.31 & 1900 & 5600 & 1400 & 1400 & [30] \\
\hline 24 & Thalictrum & 33.88 & 1.85 & 4000 & 5200 & 2000 & 2800 & [17] [30] \\
\hline 25 & Polygonum & 0.36 & 0.00 & 5100 & 5100 & 900 & 900 & {$[30]$} \\
\hline 26 & Labiatae & 3.37 & 0.26 & 3700 & 5500 & 600 & 1400 & [30] \\
\hline 27 & Rosaceae & 3.39 & 0.44 & 860 & 860 & 560 & 560 & [30] \\
\hline 28 & Potentilla & 1.29 & 0.92 & 4500 & 5600 & 2100 & 3700 & [17] [30] \\
\hline 29 & Gentiana & 0.50 & 0.04 & 5700 & 5700 & 2100 & 2100 & [30] \\
\hline 30 & Solanaceae & 0.50 & 0.04 & 5200 & 5200 & 780 & 780 & [30] \\
\hline 31 & Sedum & 0.34 & 0.18 & 5400 & 5400 & 1000 & 1000 & [30] \\
\hline 32 & Umbelliferae & 0.00 & 0.13 & 5300 & 5300 & 800 & 800 & [30] \\
\hline 33 & Lilium & 0.77 & 0.70 & 5400 & 5400 & 800 & 800 & {$[30]$} \\
\hline 34 & Cyperaceae & 3.42 & 1.50 & 4500 & 5600 & 800 & 3700 & {$[13][17][30]$} \\
\hline
\end{tabular}


the pollen zone can be semi-quantitatively estimated by its pollen assemblages respectively (Figure 5 ).

Pollen zone I is dominated by Pinus (38.6\%, 1200 - 4200 m), Picea and Abies (16.8\%, 2700 - 3700 m), Ephedra (13.1\%, 2400 - 5300 m), Lonicera $(10.8 \%, 1200$ $5200 \mathrm{~m})$, Chenopodiaceae (7.3\%, 2000 - $5500 \mathrm{~m})$, Gramineae (2.1\%, 650 - 5600 m), Thalictrum (1.9\%, 2800 - 4000 m), Cyperaceae (1.5\%, 3700 - 4500 m), Cupressaceae $(1.3 \%, 3700-4500 \mathrm{~m})$, Rosa $(1.1 \%, 860-5600 \mathrm{~m})$ and Potentilla $(1.0 \%, 3700-4500 \mathrm{~m})$. It is showing that the pollen zone I was mainly came from the belt in the elevation of $3500-3700 \mathrm{~m}$. Meanwhile, the pollen zone II is dominated by Thalictrum (33.9\%), Pinus (19.5\%), Chenopodiaceae (8.1\%), Ephedra (5.5\%), Betula (4.4\%), Gramineae (3.6\%), Labiatae (3.4\%), Rosaceae (3.4\%), Cyperaceae (3.4\%), Potentilla (1.2\%), Ulmus (1.2\%), Lonicera (1.0\%) and $R o s a(1.0 \%)$. It is showing that the pollen zone II was mainly came from the belt in the elevation of $3800-4000 \mathrm{~m}$.

In the eastern Tibetan Plateau, the subalpine dark coniferous forests are distributed in the belt range from 2800 to $3700 \mathrm{~m}$ above the sea level (asl) of Gongga Mountain [17]. The frigid dark coniferous forests are distributed in the belt range from 2800 to $3600 \mathrm{~m}$ ·asl of Gongga Mountain (Li et al., 2009). Mountain dark coniferous forests are mainly distributed in the northern slopes of some mountains at an elevation of about 3100 - $3500 \mathrm{~m}$.asl in the southeast and 2800 -

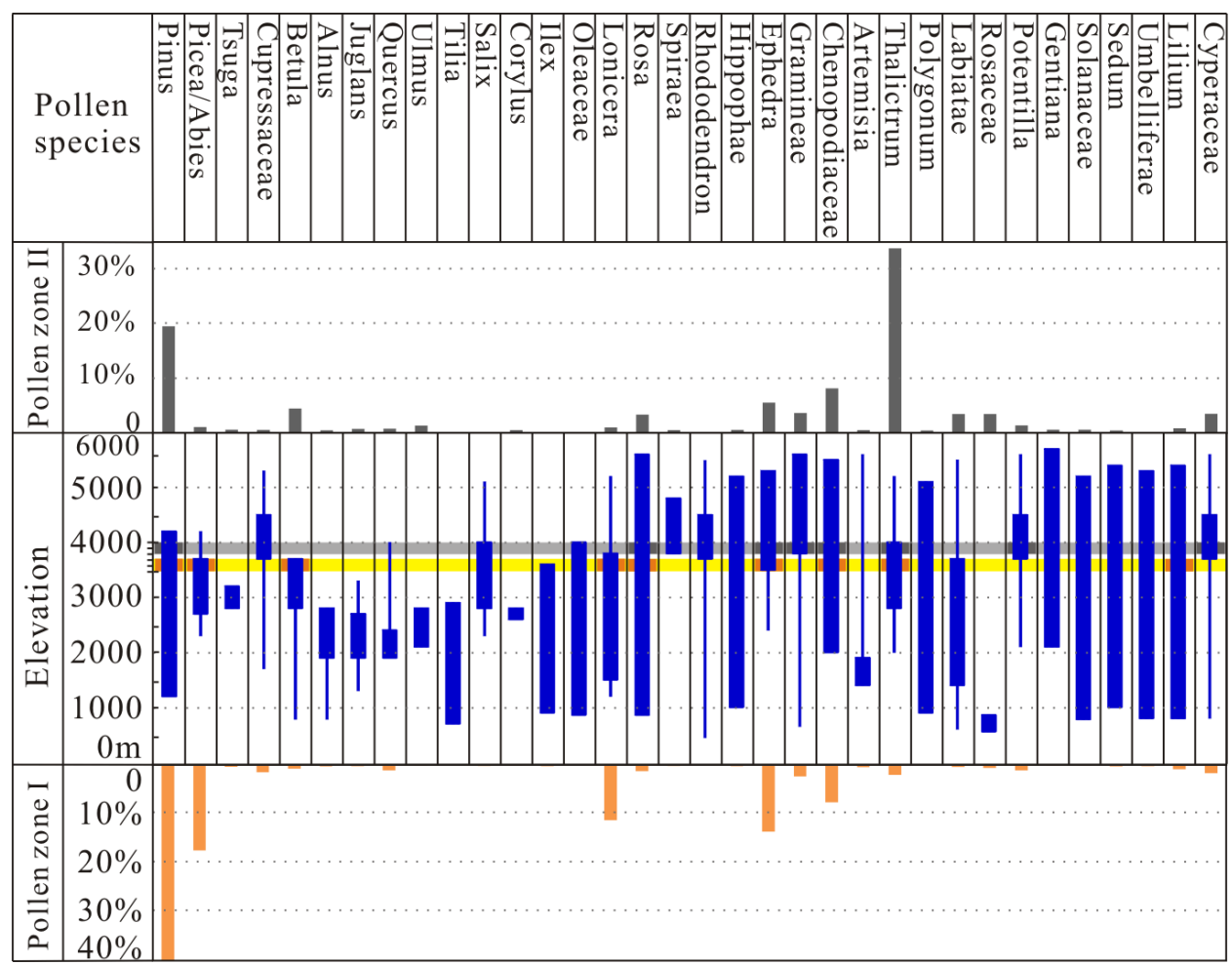

Figure 5. Plot of altitude ranges of presumed nearest living relatives of pollen taxa recovered from the eastern Tibetan Plateau. The pollen percentages of the pollen zone I and II is colored with orange and grey respectively. The distribution belt of the pollen zone I and II is expressed with the yellow and grey horizontal bars respectively. 
$3800 \mathrm{~m} \cdot$ asl in the northwest of Tibetan Plateau [37]. As mention above, the pollen zone I is mainly deposited in the subalpine dark coniferous forests environment. Hence, it is reasonable that the pollen zone I was mainly came from the belt in the elevation from 3500 to $3700 \mathrm{~m}$.

The alpine shrub meadows are distributed at an elevation of about $3700-4000$ $\mathrm{m} \cdot$ asl in Gongga Mountain [17], 3800 - $4800 \mathrm{~m} \cdot \mathrm{asl}$ in the southern slope of mid-Himalaya Mountains [38], above $3800 \mathrm{~m}$ in the eastern margin of the Tibetan Plateau [39]. As mention above, the pollen zone I is mainly deposited in the subalpine dark coniferous forests environment. Hence, it is reasonable that the pollen zone I was mainly came from the belt in the elevation of $3800-4000 \mathrm{~m}$.

The study of the Zhou et al. [40] is shows that the elevation of the Plateau surface was raised about $300 \mathrm{~m}$, from 4270 to $4570 \mathrm{~m}$ after the Gonghe Movement. Although the absolute altitude is inconsistence with our study, the rising height of the plateau surface is consistence with ours [40]. Meanwhile, our study is consistence with the paleo-elevation inferred from oxygen isotope of lacustrine deposits in the Kunlun Mountain Pass too. In the Pliocene period, the paleo-elevation was $3426 \mathrm{~m}$ from oxygen isotope of marlstone sample collected at $94^{\circ} 03^{\prime} 58^{\prime \prime} \mathrm{E}$ and $35^{\circ} 38^{\prime} 18^{\prime \prime} \mathrm{N}$ [41]. In the Pleistocene period, the paleo-elevation was $3773 \mathrm{~m}$ from oxygen isotope of marlstone sample collected at $94^{\circ} 05^{\prime} 24^{\prime \prime} \mathrm{E}$ and $35^{\circ} 38^{\prime} 42^{\prime \prime} \mathrm{N}$ [41]. The paleo-elevation was $3769 \mathrm{~m}$ from oxygen isotope of marlstone sample collected at $94^{\circ} 05^{\prime} 44^{\prime \prime} \mathrm{E}$ and $35^{\circ} 38^{\prime} 51^{\prime \prime} \mathrm{N}$ [41]. The elevation of Kunlun Mountain Pass was raised about 340 m (from 3430 to 3770 m) during the period from Pliocene to Pleistocene [41]. The modern elevation of Kunlun Mountain Pass is approximately $4780 \mathrm{~m} \cdot$ asl. The modern elevation of the study area is approximately $4932 \mathrm{~m}$, which is approximately $150 \mathrm{~m}$ higher than the Kunlun Mountain Pass. Hence, it is reasonable that the elevation of study area was raised about $300 \mathrm{~m}$ (from 3500 - $3700 \mathrm{~m}$ to $3800-4000 \mathrm{~m}$ ) during the middle-late Pleistocene.

\subsection{The Wind Direction Interpretation}

Usually, air temperature is declining with the increasing elevation. As shown above, the elevation of study area was raised about $300 \mathrm{~m}$ (from $3500-3700 \mathrm{~m}$ to $3800-4000 \mathrm{~m}$ ) during the middle-late Pleistocene. It seems to be contrary to the paleo-temperature interpretation that the climate is comparatively cooler during the pollen zone I depositional period than the pollen zone II depositional period. However, in the pollen zone I, part of the pollen (Cupressaceae, Gramineae, Cyperaceae and Potentilla) is come from higher altitude, but little is come from the lower altitude localities (Figure 5). It is indicated that the study area was located in the advection wind or down wind direction. In the pollen zone II, the pollen species are not only more numerous than them in Pollen zone I, but also the pollen assemblages in it are more complex. A little pollen (Potentilla) is coming from higher altitude localities, while a lot of pollen is come from the lower altitude localities (Tsuga, Alnus, Juglans, Quercus, Ulmus, Salix, Artemisia, Rosaceae) (Figure 5). It is indicated that the study area was located in the upwind di- 
rection. It can be concluded that the wind direction in the central of Tibetan Plateau was changed from horizontal or downward direction to upward direction at middle-late Pleistocene. During the pollen zone II depositional period, the pollen may be transported on to the high and relatively cold plateau from lower altitude warm temperate forests by upwelling wind (summer monsoon) [30], which may be resulted the characteristics that the climate is comparatively cooler during the pollen zone I depositional period than the pollen zone II depositional period.

\subsection{Influence of the Gonghe Movement}

It is known that the hottest period since the middle-Pleistocene was at approximately $120 \mathrm{ka}$ BP both in the southern hemisphere [42] [43] and northern hemisphere [8]. Meanwhile the Gonghe movement was started at $150 \mathrm{ka} \mathrm{BP}$ and persisted for about $50 \mathrm{ka} \mathrm{[10]} \mathrm{[11]} \mathrm{(Figure} \mathrm{6).} \mathrm{Hence,} \mathrm{many} \mathrm{studies} \mathrm{regard} \mathrm{the}$ Plateau uplift as a possible driving force for the simultaneous enhancement of East Asian winter and summer monsoons as well as for the Mid-Pleistocene transition occurrence [44] [45]. However, some authors suggest that the midPliocene climate changes in East Asia are unlikely to be a response to Plateau uplift [46].

As shown above, the elevation of study area was raised about $300 \mathrm{~m}$ (from $3500-3700 \mathrm{~m}$ to $3800-4000 \mathrm{~m}$ ) during the middle-late Pleistocene. As the elevation increased, the temperature would be decreased about $1.8^{\circ} \mathrm{C}$ calculated with an air temperature gradient of $6 \mathrm{~K} / \mathrm{km}$. However, the MIS (marine isotope stage) curve shows that the annual temperature raised about $8^{\circ} \mathrm{C}$ after the Gonghe movement (Figure 3). In the central of Tibetan Plateau, the temperature was slightly elevated in the middle-late Pleistocene. The climate change in the central of Tibetan Plateau was corresponding with the global climate change at the middle-late Pleistocene.

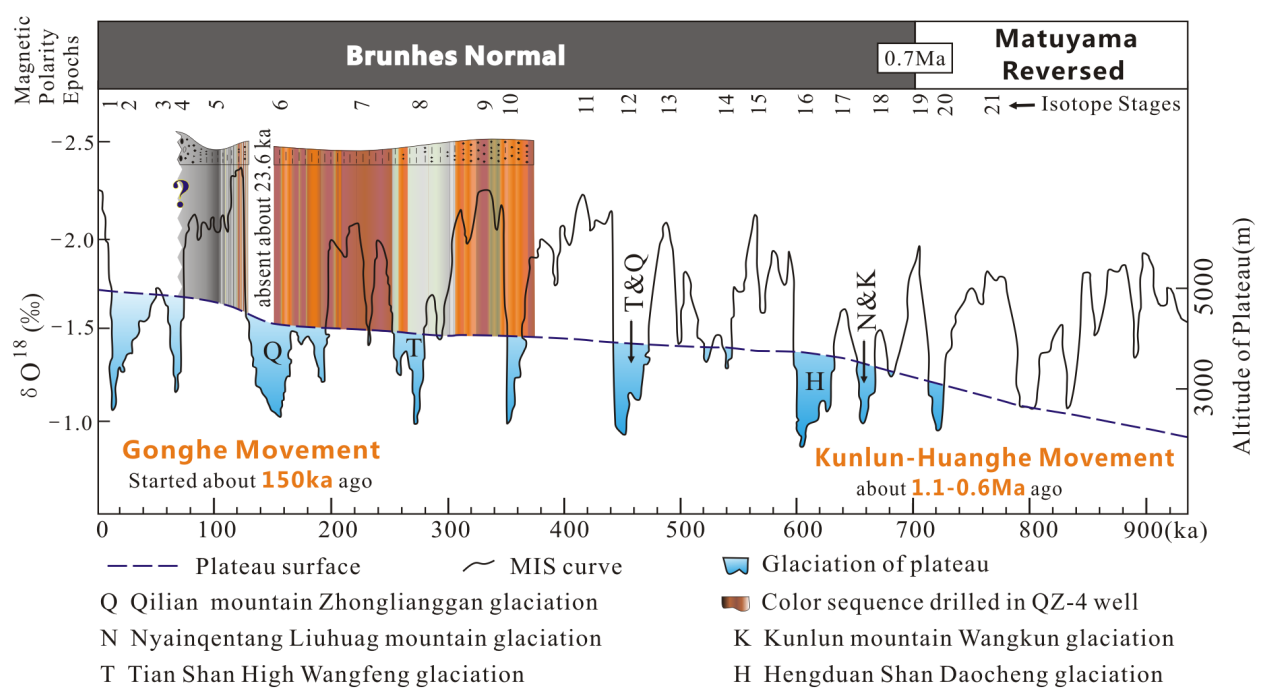

Figure 6. The coupling relationship between the uplift of Tibet Plateau and quaternary climate evolution (modified from reference [10]). 
In another face, the paleo-climate during pollen zone I deposition period was comparatively wetter than it during the pollen zone II, which is shown that the barrier effect of Tibetan Plateau to moisture is stronger and stronger with the elevation increasing of Tibetan Plateau. Hence, it can be concluded that the climate change in the central of Tibetan Plateau at the middle-late Pleistocene documented by the well QZ-4 core seems to be mainly driven by global climate change, and that tectonic uplift may have been a subordinate influence.

\section{Conclusions}

The comprehensive paleo-climate and paleo-altimetry studies of the pollen samples from the well QZ-4, in the centre of Tibetan Plateau, lead to the following conclusions:

1) In the well QZ-4, the pollen assemblage can obviously divided into two pollen zones. Pollen zone I (251.1 - $314 \mathrm{~m}$ in depth, 120.0 - $345.8 \mathrm{ka} \mathrm{BP}$.) is characterised by single species and low pollen concentrations. Pollen zone II (200 $251.1 \mathrm{~m}$ in depth, 105.4 - $120 \mathrm{ka}$ BP.) is characterised by multiple species and high pollen concentrations.

2) The paleo-climate during pollen zone I was comparatively colder and wetter than it during the pollen zone II.

3) The paleo-elevation of pollen zone I is concentrated on the belt in the elevation from 3500 to $3700 \mathrm{~m}$. The paleo-elevation of pollen zone II is mainly come from the belt in the elevation from 3800 to $4000 \mathrm{~m}$. The study area had been uplifted about $300 \mathrm{~m}$ after the Gonghe Movement.

4) In the centre of Tibetan Plateau, the wind had changed from horizontal or downwelling wind to upwelling wind, in the middle-late Pleistocene.

5) In the central of Tibetan Plateau, the climate change seems to be mainly driven by global climate change, and that tectonic uplift may have been a subordinate influence in the middle-late Pleistocene.

\section{Acknowledgements}

This study was supported by the National Natural Science Foundation of China Nos. 41302092. Grateful acknowledgements are made to the Xizang Geothermal Geological Brigade, which provided the field help during the drilling process. Guobang Tong and Songmei Tong, coming from Institute of Hydrogeology and Environmental Geology, Chinese Academy of Geological Sciences, provided assistance for the identification of pollen. Jinhui Cheng, coming from Nanjing Institute of Geology and Palaeontology, Academic Sinicagave much help during sample preparation.

\section{References}

[1] He, J., Wang, J., Fu, X., Zheng, C. and Chen, Y. (2012) Assessing the Conditions Favorable for the Occurrence of Gas Hydrate in the Tuonamu Area Qiangtang Basin, Qinghai-Tibetan, China. Energy Conversion and Management, 53, 11-18. 
[2] Zhang, X. and Yang, T. (2015) Environmental Impacts of Hydraulic Fracturing in Shale Gas Development in the United States. Petroleum Exploration and Development, 42, 876-883.

[3] Hoorn, C., Straathof, J., Abels, H.A., Xu, Y., Utescher, T. and Dupont-Nivet, G. (2012) A Late Eocene Palynological Record of climate Change and Tibetan Plateau Uplift (Xining Basin, China). Palaeogeography, Palaeoclimatology, Palaeoecology, 344-345, 16-38.

[4] Xiao, G., Guo, Z., Dupont-Nivet, G., Lu, H., Wu, N., Ge, J., Hao, Q., Peng, S., Li, F., Abels, H.A. and Zhang, K. (2012) Evidence for Northeastern Tibetan Plateau Uplift between 25 and 20Ma in the Sedimentary Archive of the Xining Basin, Northwestern China. Earth and Planetary Science Letters, 317-318, 185-195.

[5] Li, S., Zhang, H., Shi, Y. and Zhu, Z. (2008) A High Resolution MIS 3 Environmental Change Record Derived from Lacustrine Depostit of Tianshuihai Lake, Qinghai-Tibet Plateau. Quaternary Sciences, 28, 122-131.

[6] Yu, S., Zhu, Z., Li, S., Li, B., Zhou, H. and Sun, Y. (1997) Environmental Records of Variation of Iron Oxides in Drill Core from Tianshuihai Lake on the Southern Flanke of West Kunlun Mountains. Geochemica, 26, 88-98.

[7] Yamamoto, K., Yamashita, F. and Adachi, M. (2005) Precise Determination of REE for Sedimentary Reference Rocks Issued by the Geological Survey of Japan. Geochemical Journal, 39, 289-297.

[8] Dahl-Jensen, D., Albert, M.R., Aldahan, A., Azuma, N., Balslev-Clausen, D., Baumgartner, M., Berggren, A.-M., Bigler, M., Binder, T. and Blunier, T. (2013) Eemian Interglacial Reconstructed from a Greenland Folded Ice Core. Nature, 493, 489-494. https://doi.org/10.1038/nature11789

[9] Yi, H., Zhu, X. and Zhu, Y. (2006) Lake Level Change Recorded by Core of the Quaternary Lacustrine Sediment in the Central Tibetan Plateau and Its Climatic Implications. Earth Science Frontiers, 13, 300-307.

[10] Li, J. (1991) The Environmental Effects of the Uplift of the Qinghai-Xizang Plateau. Quaternary Science Reviews, 10, 479-483. https://doi.org/10.1016/0277-3791(91)90041-R

[11] Qiao, Y., Qi, L., Liu, Z., Wang, Y., Yao, H., Yang, J. and Zhao, Z. (2014) Intensification of Aridity in the Eastern Margin of the Tibetan Plateau since 300 ka BP Inferred from Loess-Soil Sequences, Western Sichuan Province, Southwest China. $\mathrm{Pa}$ laeogeography, Palaeoclimatology, Palaeoecology, 414, 192-199. https://doi.org/10.1016/j.palaeo.2014.08.025

[12] He, J., Wang, J., Sun, W., Zheng, C., Li, W., Guo, T. and Zeng, S. (2016) Geochemical Characteristics of Lake Clay Drilled in Well QZ-4: Its Implication for Geochemical Response to Climate Change in the Central Tibetan Plateau in the Middle-Late Pleistocene. Environmental Earth Sciences, 75, 1-14. https://doi.org/10.1007/s12665-016-6119-y

[13] Lu, H., Wu, N., Liu, K.-B., Zhu, L., Yang, X., Yao, T., Wang, L., Li, Q., Liu, X., Shen, C., Li, X., Tong, G. and Jiang, H. (2011) Modern Pollen Distributions in Qinghai-Tibetan Plateau and the Development of Transfer Functions for Reconstructing Holocene Environmental Changes. Quaternary Science Reviews, 30, 947-966. https://doi.org/10.1016/j.quascirev.2011.01.008

[14] Zhao, K., Li, X., Dodson, J., Atahan, P., Zhou, X. and Bertuch, F. (2012) Climatic Variations over the Last $4000 \mathrm{cal}$ yr BP in the Western Margin of the Tarim Basin, Xinjiang, Reconstructed from Pollen Data. Palaeogeography, Palaeoclimatology, Palaeoecology, 321-322, 16-23. https://doi.org/10.1016/j.palaeo.2012.01.012 
[15] Wu, F., Herrmann, M. and Fang, X. (2014) Early Pliocene Paleo-Altimetry of the Zanda Basin Indicated by a Sporopollen Record. Palaeogeography, Palaeoclimatology, Palaeoecology, 412, 261-268. https://doi.org/10.1016/j.palaeo.2014.08.006

[16] Xiao, X., Shen, J. and Wang, S. (2011) Spatial Variation of Modern Pollen from Surface Lake Sediments in Yunnan and Southwestern Sichuan Province, China. Review of Palaeobotany and Palynology, 165, 224-234.

https://doi.org/10.1016/j.revpalbo.2011.04.001

[17] Li, Q., Ge, Q. and Tong, G. (2012) Modern Pollen-Vegetation Relationship Based on Discriminant Analysis across an Altitudinal Transect on Gongga Mountain, Eastern Tibetan Plateau. Chinese Science Bulletin, 57, 4600-4608. https://doi.org/10.1007/s11434-012-5236-6

[18] Cordova, C.E. (2007) Holocene Mediterranization of the Southern Crimean Vegetation: Paleoecological Records, Regional Climate Change and Possible Non-Climatic Influences. In: Yanko-Hombach, V., Gilbert, A.S., Panin, N. and Dolukhanov, P.M., Eds., The Black Sea Flood Question: Changes in Coastline, Climate and Human Settlement, Springer, Dordrecht, 319-344. https://doi.org/10.1007/978-1-4020-5302-3_13

[19] Good, R.E. and Good, N.F. (1975) Growth Characteristics of Two Populations of Pinus rigida Mill. from the Pine Barrens of New Jersey. Ecology, 56, 1215-1220. https://doi.org/10.2307/1936162

[20] Jaimand, K., Nejad, S., Monfared, A. and Akbarzadeh, M. (2014) Study of the Chemical Composition of Essential Oil of Teucrium chamaedrys at the Different Distillation in Mazandaran Province. Journal of Medicinal Plants and By-Products, 3, 193-198.

[21] Li, Y., Sun, X., Zhao, X., Zhao, L., Xu, S., Gu, S., Zhang, G.F. and Yu, G. (2006) Seasonal Variations and Mechanism for Environmental Control of NEE of CO2 Concerning the Potentilla Fruticosa in Alpine Shrub Meadow of Qinghai-Tibet Plateau. Science in China Series D: Earth Sciences, 49, 174-185. https://doi.org/10.1007/s11430-006-8174-9

[22] Ji, S., Xingqi, L., Sumin, W. and Matsumoto, R. (2005) Palaeoclimatic Changes in the Qinghai Lake Area during the Last 18,000 Years. Quaternary International, 136, 131-140. https://doi.org/10.1016/j.quaint.2004.11.014

[23] Zhao, Y., Yu, Z., Chen, F., Liu, X. and Ito, E. (2008) Sensitive Response of Desert Vegetation to Moisture Change Based on a Near-Annual Resolution Pollen Record from Gahai Lake in the Qaidam Basin, Northwest China. Global and Planetary Change, 62, 107-114. https://doi.org/10.1016/j.gloplacha.2007.12.003

[24] Wafa'a, A., Al-Qarawi, A.A. and Alsubiee, M.S. (2010) Effect of Water Stress by Polyethylene Glycol 8000 and Sodium Chloride on Germination of Ephedra alata decne Seeds. Saudi Journal of Biological Sciences, 17, 253-257. https://doi.org/10.1016/j.sjbs.2010.04.011

[25] Zhang, J., Wu, B., Zhu, Y., Li, Y., Lu, Q. and Yao, B. (2013) Responses of Nitraria tangutorum to Water and Photosynthetic Physiology in Rain Enrichment Scenario. Acta Ecologica Sinica, 33, 172-177. https://doi.org/10.1016/j.chnaes.2013.03.008

[26] Gentry, A.H., Bullock, S., Mooney, H.A. and Medina, E. (1995) Seasonally Dry Tropical Forests. Cambridge University Press, Cambridge.

[27] Fujii, R. and Sakai, H. (2002) Paleoclimatic Changes during the Last 2.5 myr Recorded in the Kathmandu Basin, Central Nepal Himalayas. Journal of Asian Earth Sciences, 20, 255-266. https://doi.org/10.1016/S1367-9120(01)00048-7

[28] Herzschuh, U. (2007) Reliability of Pollen Ratios for Environmental Reconstruc- 
tions on the Tibetan Plateau. Journal of Biogeography, 34, 1265-1273. https://doi.org/10.1111/j.1365-2699.2006.01680.x

[29] Chuanhu, Z. and Xing, C. (2010) Climatological Significance of Pollen Factors Revealed by Pollen-Climate Response Surface Functions in Dajiuhu, Shennongjia. Journal of Meteorological Research, 24, 699-712.

[30] Song, X.-Y., Spicer, R.A., Yang, J., Yao, Y.-F. and Li, C.-S. (2010) Pollen Evidence for an Eocene to Miocene Elevation of Central Southern Tibet Predating the Rise of the High Himalaya. Palaeogeography, Palaeoclimatology, Palaeoecology, 297, 159168. https://doi.org/10.1016/j.palaeo.2010.07.025

[31] Xu, Q., Ding, L., Zhang, L., Cai, F., Lai, Q., Yang, D. and Liu-Zeng, J. (2013) Paleogene High Elevations in the Qiangtang Terrane, Central Tibetan Plateau. Earth and Planetary Science Letters, 362, 31-42. https://doi.org/10.1016/j.epsl.2012.11.058

[32] Sun, J., Xu, Q., Liu, W., Zhang, Z., Xue, L. and Zhao, P. (2014) Palynological Evidence for the Latest Oligocene-Early Miocene Paleoelevation Estimate in the Lunpola Basin, Central Tibet. Palaeogeography, Palaeoclimatology, Palaeoecology, 399, 21-30. https://doi.org/10.1016/j.palaeo.2014.02.004

[33] Xianhao, Z., Wenjing, Z. and Ji, L. (1999) The Characteristics of the Mountain Ecosystem and Environment in the Gongga Mountain Region. Joint Seminar on Ecosystem Research and Management in China, 28, 648-654.

[34] Cheng, G. and Luo, J. (2001) Successional Features and Dynamic Simulation of Sub-Alpine Forest in the Gongga Mountain, China. Acta Ecologica Sinica, 22, 10491056.

[35] Wang, X., Song, C., Wang, J., Miao, Y., Mao, R. and Song, Y. (2013) Carbon Release from Sphagnum Peat during Thawing in a Montane Area in China. Atmospheric Environment, 75, 77-82. https://doi.org/10.1016/j.atmosenv.2013.04.056

[36] Cai, Y., Zhang, H., Cheng, H., An, Z., Lawrence Edwards, R., Wang, X., Tan, L., Liang, F., Wang, J. and Kelly, M. (2012) The Holocene Indian Monsoon Variability over the Southern Tibetan Plateau and Its Teleconnections. Earth and Planetary Science Letters, 335, 135-144. https://doi.org/10.1016/j.epsl.2012.04.035

[37] Lu, H., Wu, N., Gu, Z., Guo, Z., Wang, L., Wu, H., Wang, G., Zhou, L., Han, J. and Liu, T. (2004) Distribution of Carbon Isotope Composition of Modern Soils on the Qinghai-Tibetan Plateau. Biogeochemistry, 70, 275-299. https://doi.org/10.1023/B:BIOG.0000049343.48087.ac

[38] Lu, C. (2014) Spatial Distributing Characteristics of Land Use in the Southern Slope of Mid-Himalaya Mountains. In: International Society for Optics and Photonics, SPIE Asia Pacific Remote Sensing, International Society for Optics and Photonics, Bellingham, $92604 \mathrm{~N}-92604 \mathrm{~N}-7$.

[39] Zhou, W., Yu, S.Y., Burr, G.S., Kukla, G.J., Jull, A., Xian, F., Xiao, J., Colman, S.M., Yu, H. and Liu, Z. (2010) Postglacial Changes in the Asian Summer Monsoon System: A Pollen Record from the Eastern Margin of the Tibetan Plateau. Boreas, 39, 528-539.

[40] Zhou, S., Wang, X., Wang, J. and Xu, L. (2006) A Preliminary Study on Timing of the Oldest Pleistocene Glaciation in Qinghai-Tibetan Plateau. Quaternary International, 154, 44-51. https://doi.org/10.1016/j.quaint.2006.02.002

[41] Wu, Z., Zhao, X., Ye, P., Hu, D. and Zhou, C. (2007) Paleo-Elevation of the Tibetan Plateau Inferred from Carbon and Oxygen Isotopes of Lacustrine Deposits. Acta Geologica Sinica, 81, 1277-1288.

[42] Vimeux, F.O., Cuffey, K.M. and Jouzel, J. (2002) New Insights into Southern He- 
misphere Temperature Changes from Vostok Ice Cores Using Deuterium Excess Correction. Earth and Planetary Science Letters, 203, 829-843. https://doi.org/10.1016/S0012-821X(02)00950-0

[43] Yamamoto, Y., Kitahara, N. and Kano, M. (2012) Long Memory Effect of Past Climate Change in Vostok Ice Core Records. Thermochimica Acta, 532, 41-44. https://doi.org/10.1016/j.tca.2011.11.033

[44] Liu, D., Fang, X., Song, C., Dai, S., Zhang, T., Zhang, W., Miao, Y., Liu, Y. and Wang, J. (2010) Stratigraphic and Paleomagnetic Evidence of Mid-Pleistocene Rapid Deformation and Uplift of the NE Tibetan Plateau. Tectonophysics, 486, 108119. https://doi.org/10.1016/j.tecto.2010.01.014

[45] Han, W., Fang, X. and Berger, A. (2012) Tibet Forcing of Mid-Pleistocene Synchronous Enhancement of East Asian Winter and Summer Monsoons Revealed by Chinese Loess Record. Quaternary Research, 78, 174-184.

https://doi.org/10.1016/j.yqres.2012.05.001

[46] Ge, J., Dai, Y., Zhang, Z., Zhao, D., Li, Q., Zhang, Y., Yi, L., Wu, H., Oldfield, F. and Guo, Z. (2013) Major Changes in East Asian Climate in the Mid-Pliocene: Triggered by the Uplift of the Tibetan Plateau or Global Cooling? Journal of Asian Earth Sciences, 69, 48-59. https://doi.org/10.1016/j.jseaes.2012.10.009

Submit or recommend next manuscript to SCIRP and we will provide best service for you:

Accepting pre-submission inquiries through Email, Facebook, LinkedIn, Twitter, etc. A wide selection of journals (inclusive of 9 subjects, more than 200 journals) Providing 24-hour high-quality service

User-friendly online submission system

Fair and swift peer-review system

Efficient typesetting and proofreading procedure

Display of the result of downloads and visits, as well as the number of cited articles Maximum dissemination of your research work

Submit your manuscript at: http://papersubmission.scirp.org/

Or contact gep@scirp.org 